\title{
GANGGUAN FUNGSI GINJAL PADA IBU HAMIL PREEKLAMPSIA BERAT DENGAN DISLIPIDEMIA DI RSUD KELAS B SERANG
}

\section{Renal Function Disturbance in Severe Preeclamptic Women with Dyslipidemia at RSUD Class B Serang}

\author{
Muttia Amalia $^{1 *}$, Erna Harfiani ${ }^{2}$, Aulia Chairani ${ }^{3}$ \\ ${ }^{1}$ Departemen Patologi Klinik, Fakultas Kedokteran UPN Veteran Jakarta \\ ${ }^{2}$ Departemen Farmakologi, Fakultas Kedokteran UPN Veteran Jakarta \\ ${ }^{3}$ Departemen Kesehatan Masyarakat, Fakultas Kedokteran UPN Veteran Jakarta \\ E-mail: muttia.aw@gmail.com
}

Naskah masuk 15 Desember 2019; review 19 Desember 2019; disetujui terbit 26 Juni 2020

\begin{abstract}
Background: Preeclampsia is one of the leading causes of maternal-fetal morbidity and mortality in developing countries. Dyslipidemia in severely preeclamptic women will develop end-organ damage due to endothelial dysfunction.

Objective: The objective of this study was to evaluate the correlation between blood lipid profile and renal function in severely preeclamptic women at RSUD Class B Serang district, January-December 2018.

Method: This study was an analytical observational study with a cross-sectional design. Conducted using total sampling technique, 103 pregnant women were included from medical records. Data were analyzed using correlation tests and logistic regression.

Result: Correlation analysis indicates that HDL level $(<60 \mathrm{mg} / \mathrm{dL})$ and $L D L$ level $(>160 \mathrm{mg} / \mathrm{dL})$ had a significant impact in the alteration of urea and creatinine level in severe PE. Logistic regression analysis signifies that only decreased level of HDL had a significant partial impact on increasing creatinine levels ( $p=0,013$ OR=1,107).

Conclusion: The conclusion of this study was in severe PE women there was an increased level of TG and LDL, with a decreased level of HDL. Dyslipidemia in severe PE women will lead to oxidative stress and endothelial dysfunction, which further will cause alteration in glomerulus structure and disturbance of renal function.
\end{abstract}

Keywords: dyslipidemia, creatinine, severe PE, urea

\begin{abstract}
Abstrak
Latar Belakang: Preeklampsia (PE) merupakan salah satu penyebab utama kesakitan dan kematian ibu dan bayi di negara berkembang. Dislipidemia pada ibu hamil dengan preeklampsia berat (PEB) akan menyebabkan endorgan damage akibat disfungsi endotel.

Tujuan: Tujuan penelitian ini adalah untuk menilai hubungan antara profil lipid darah terhadap gangguan fungsi ginjal pada ibu hamil dengan preeklampsia berat di RSUD Kelas B Serang periode Januari - Desember 2018.

Metode: Penelitian ini merupakan penelitian observasi analitik dengan pendekatan cross sectional. Menggunakan teknik total sampling, sebanyak 103 sampel diambil dari data rekam medik. Data dianalisis menggunakan uji korelasi dan regresi logistik.

Hasil: Hasil korelasi menunjukkan bahwa kadar HDL yang lebih rendah $(<60 \mathrm{mg} / \mathrm{dL})$ dan kadar LDL yang lebih tinggi ( $>160 \mathrm{mg} / \mathrm{dL}$ ) memiliki hubungan yang bermakna terhadap peningkatan kadar ureum dan kreatinin pada bumil dengan PEB. Analisis regresi logistik memperlihatkan bahwa hanya kadar HDL yang menurun memiliki hubungan parsial yang signifikan terhadap peningkatan kadar kreatinin $(\mathrm{p}=0,013 \mathrm{OR}=1,107)$.

Kesimpulan: Kesimpulan penelitian ini bahwa telah ditemukan peningkatan kadar trigliserida (TG) dan LDL serta penurunan kadar HDL pada bumil dengan PEB. Dislipidemia pada PEB akan menyebabkan stres oksidasi dan disfungsi endotel yang selanjutnya akan menyebabkan perubahan struktur glomerulus dan perubahan fungsi ginjal
\end{abstract}

Kata kunci: dislipidemia, kreatinin, PEB, ureum 


\section{PENDAHULUAN}

Kematian maternal pada tingkat dunia secara global masih tinggi hingga saat ini. Hampir 99\% tingkat kematian pada ibu akibat hamil dan melahirkan terjadi di negara-negara berkembang. Data WHO di tahun 2015, mengungkapkan kematian maternal diperkirakan sejumlah 303.000 wanita, atau sekitar 830 wanita setiap harinya akibat berbagai komplikasi akibat kehamilan atau persalinan. Komplikasi utama penyebab kematian maternal, sekitar $75 \%$ disebabkan perdarahan hebat, infeksi serta tekanan darah tinggi selama kehamilan (preeklampsia dan eklampsia). ${ }^{1}$

Kasus preeklampsia (PE) di negara berkembang terjadi pada sekitar $6-8 \%$ kehamilan. Preeklampsia merupakan salah satu komplikasi utama penyebab tingginya tingkat kesakitan dan kematian ibu dan bayi. Hal ini perlu diwaspadai karena PE merupakan kejadian yang berbahaya dalam kehamilan, yang ditandai dengan hipertensi (tekanan darah sistolik $\geq 140$ dan tekanan darah diastolik $\geq 90$ ) serta terjadi proteinuria ( $\geq 300 \mathrm{mg} / 24$ jam atau persisten +1 dengan dipstick) yang dapat muncul sejak awal kehamilan, namun umumnya lebih sering terjadi setelah kehamilan minggu ke-20. ${ }^{2}$

Preeklampsia merupakan sindrom multisistemik, penyebabnya meliputi faktor genetik dan lingkungan. Penatalaksanaan terbaik dari PE adalah dengan segera melahirkan bayi dan plasenta dari rahim ibu/terminasi kehamilan. Hipotesis sentral menyatakan bahwa preeklampsia terjadi akibat kegagalan pada proses remodelling arteri spiralis di plasenta. Hal ini menyebabkan ketidakseimbangan pada faktor anti-angiogenik dan pro-angiogenik. Keadaan ketidakseimbangan ini akan menyebabkan terjadinya disfungsi endotel yang akan mengganggu proses aliran darah dari uterus ke plasenta dan berpotensi membahayakan proses perkembangan janin akibat gangguan pembuluh darah arteri plasenta yang menyebabkan bayi akan mengalami

*Korespondensi: muttia.aw@ gmail.com

(C) Badan Penelitian dan Pengembangan Kesehatan ISSN: 2354-8762 (elektronik); ISSN: 2087-703X (cetak) kekurangan suplai darah dan oksigen dari ibunya. $^{3}$

Penanda yang dapat digunakan untuk keadaan lebih lanjut dari PE adalah homeostasis kolesterol. Ketidakseimbangan kadar kolesterol (dislipidemia) berperan terhadap kejadian preeklampsia, sama seperti perannya pada penyakit kardiovaskular. Terdapat beberapa mekanisme patofisiologi yang telah diteliti sebagai asosiasi antara perubahan metabolik kolesterol dan PE. Dislipidemia memicu disfungsi endotel yang terjadi pada arteri spiralis plasenta, sehingga menyebabkan stres oksidatif yang berlebihan. Mekanisme stres oksidatif ini akan menyebabkan pada ganggauan metabolisme glukosa dan lipid pada ibu hamil, yang memicu timbulnya keadaan dislipidemia. Dislipidemia merupakan salah satu faktor yang memicu timbulnya sindroma metabolik dan kelainan vaskular yang terkait lainnya. Secara umum, dislipidemia berkaitan erat dengan obesitas dan kelainan kardiovaskular jangka panjang pada pasien dengan PEB. ${ }^{4}$

Ginjal mengalami adaptasi fisiologis dalam kehamilan. Ibu hamil akan mengalami hiperfiltrasi glomerular hingga sekitar 40-60 persen pada trimester kedua. Keadaan ini terjadi akibat terjadinya penurunan tekanan onkotik. Pada kehamilan normal, terjadi peningkatan effective renal plasma flow (ERPF). Pada ibu hamil dengan preeklampsia, glomerular filtration rate (GFR) ginjal mengalami penurunan jika dibandingkan dengan wanita dengan kehamilan normal. Mekanisme hemodinamik dan perubahan struktur renal meliputi gangguan pada endotelial dan biologi podosit diajukan sebagai mekanisme terjadinya hipofiltrasi dalam preeklampsia. $^{5}$

Berdasarkan data di atas, penelitian ini dilakukan dengan tujuan untuk mengetahui hubungan antara profil lipid darah terhadap gangguan fungsi ginjal pada ibu hamil dengan preeklampsia berat di RSUD Kelas B Serang periode Januari - Desember 2018. Walaupun telah diketahui dari penelitian sebelumnya 
adanya hubungan dislipidemia dengan PEB, namun penelitian ini berkontribusi lebih jauh untuk mengetahui apakah dislipidemia tersebut berhubungan dengan adanya gangguan pada fungsi filtrasi glomerulus ginjal yang ditandai dengan peningkatan nilai kreatinin dan ureum di atas normal sebelum proteinuria terjadi.

\section{METODE}

Penelitian ini menggunakan studi analitik observasional dengan pendekatan potong lintang atau cross-sectional. Pengambilan sampel dari data rekam medik dengan total sampel sejumlah 103 pasien. Metode yang digunakan bersifat deskriptif analitik berdasarkan data rekam medis pasien preeklampsia berat periode 1 Januari-31 Desember 2018 di RSUD Kelas B Serang.

Preeklampsia didefinisikan sebagai keadaan timbulnya tekanan darah $>140 / 90 \mathrm{mmHg}$ dan proteinuria $>30 \mathrm{mg}$ pada ibu hamil tanpa riwayat hipertensi sebelumnya, tanpa riwayat penyakit ginjal, tanpa kelainan endokrin dan tanpa riwayat kelainan metabolisme lipid atau karbohidrat. Sementara, PEB didefinisikan jika pada keadaan PE didapatkan salah satu kelainan berikut: 1) Tekanan darah sistolik $160 \mathrm{mmHg}$ atau lebih atau tekanan darah diastolik 110 $\mathrm{mmHg}$ atau lebih; 2) Terdapat gangguan fungsi hepatik yang ditandai adanya peningkatan kadar enzim hepatik; 3) Gangguan ginjal progresif yang ditandai dengan konsentrasi kreatinin $>1,1 \mathrm{mg} / \mathrm{dL}$; 4) Gangguan visual atau serebral yang baru terjadi; 5) Edema pulmoner; dan 6) Trombositopenia. ${ }^{6}$

Keadaan dislipidemia didefinisikan sebagai peningkatan abnormal kadar kolesterol dan trigliserida. Pemeriksaan trigliserida dan kolesterol pada awal kehamilan berhubungan positif dengan PE. Sementara pemeriksaan kolesterol total, low-density lipoprotein (LDL) dan non high-density lipoprotein (non HDL) dan trigliserida disebutkan memiliki hubungan positif dengan peningkatan tekanan darah dalam kehamilan serta periode setelah kehamilan. $^{7}$ Berdasarkan hal tersebut, penelitian menggunakan kadar trigliserida, HDL, dan LDL untuk menilai kaitan profil lipid terhadap gangguan fungsi ginjal pada ibu hamil dengan PEB. Kriteria untuk penilaian kadar trigliserida, HDL serta LDL dilakukan berdasarkan Pedoman Pengelolaan Dislipidemia di Indonesia 2019. ${ }^{8}$ Adapun kriteria untuk kadar ureum dan kreatinin sebagai penanda penurunan fungsi ginjal diambil dari rujukan rentang batas normal kadar ureum dan kreatinin untuk pemeriksaan fungsi ginjal yang digunakan di Laboratorium Patologi Klinik. ${ }^{9}$

Kriteria inklusi penelitian adalah: 1) Ibu hamil trimester 3, berusia antara 17-55 tahun dengan PEB; 2) Ibu hamil trimester 3 tanpa riwayat sakit jantung, paru, ginjal, atau kelainan neurologi sebelum kehamilan; dan 3) Ibu hamil dengan data laboratorium lengkap. Sedangkan kriteria eksklusi pada penelitian ini adalah semua pasien yang diperkirakan mengganggu pelaksanaan penelitian yakni tidak memiliki tempat tinggal yang tetap, alamat yang jelas, dan data yang kurang lengkap.

Variabel bebas (independent) dalam penelitian ini adalah kadar lipid darah pasien ibu hamil dengan PEB. Variabel terikat (dependent) pada penelitian ini adalah kadar ureum kreatinin sebagai penanda gangguan fungsi ginjal.

\section{HASIL}

Karakteristik subjek penelitian berdasarkan usia menunjukkan bahwa usia ibu hamil yang mengalami PEB paling banyak ada di rentang usia 26 - 35 tahun yang merupakan rentang usia reproduksi produktif. Sedangkan untuk karakteristik subjek berdasarkan paritas menunjukkan bahwa kejadian PEB dengan frekuensi tertinggi dialami oleh wanita dengan kehamilan kedua.

Penentuan tingkat tekanan darah dilakukan berdasarkan JNC7 (The Seventh Joint National Committee) dan selanjutnya berdasarkan hasil tingkat tekanan darah, subjek akan dikelompokkan menjadi PE dan PEB berdasarkan kriteria kelainan tersebut. Pada Tabel 1 didapatkan bahwa karakteristik subjek berdasarkan hasil pengukuran tekanan darah menunjukkan bahwa ibu hamil walaupun telah menjalani pengobatan untuk terapi hipertensi tetap mengalami hipertensi stadium 1 dan 2 . Frekuensi tertinggi adalah hipertensi stadium 2.

Karakteristik subjek berdasarkan kadar TG menunjukkan bahwa ibu hamil dengan PEB frekuensi terbesar mengalami kadar trigliserida 
yang tinggi dengan sebagian kecil kadar yang normal. Sedangkan karakteristik subjek berdasarkan kadar HDL menunjukkan bahwa ibu hamil dengan PEB frekuensi terbesar mengalami kadar HDL optimal. Karakteristik subjek berdasarkan kadar LDL menunjukkan bahwa ibu hamil dengan PEB frekuensi terbesar didapatkan pada ibu hamil dengan kadar LDL tinggi disusul dengan kadar dengan batas tinggi, bagus, sangat tinggi, dan frekuensi yang terkecil adalah kadar yang paling diinginkan. Sedangkan karakteristik subjek berdasarkan kadar ureum dan kreatinin menunjukkan bahwa ibu hamil dengan PEB frekuensi terbesar mengalami kadar ureum dan kreatinin dalam batas normal.

Tabel 1. Karakteristik Responden Ibu Hamil dengan PEB

\begin{tabular}{|c|c|c|}
\hline Karakteristik & $\mathbf{n}$ & $\%$ \\
\hline \multicolumn{3}{|l|}{ Usia } \\
\hline $17-25$ tahun & 24 & 23,3 \\
\hline 26-35 tahun & 50 & 48,5 \\
\hline 36-45 tahun & 28 & 27,2 \\
\hline $46-55$ tahun & 1 & 1,0 \\
\hline \multicolumn{3}{|l|}{ Paritas } \\
\hline Primigravida & 22 & 21,4 \\
\hline Secundigravida & 31 & 30,1 \\
\hline Multigravida & 27 & 26,2 \\
\hline Grande multigravida & 23 & 22,3 \\
\hline \multicolumn{3}{|l|}{ Tekanan darah } \\
\hline Normal (<120/80 mmHg) & 0 & 0 \\
\hline Pre-hipertensi $(120-139 / 80-89 \mathrm{mmHg})$ & 0 & 0 \\
\hline Stadium $1(140-159 / 90-99 \mathrm{mmHg})$ & 39 & 37,9 \\
\hline Stadium $2(>160 / 100 \mathrm{mmHg})$ & 64 & 62,1 \\
\hline \multicolumn{3}{|l|}{ Kadar Trigliserida } \\
\hline Normal $(<150)$ & 0 & 0 \\
\hline Borderline (150 - 199) & 9 & 8,7 \\
\hline Tinggi (>200) & 94 & 91,3 \\
\hline \multicolumn{3}{|l|}{ Kadar HDL } \\
\hline Baik $(>60)$ & 65 & 63,1 \\
\hline Tidak optimal $(41-59)$ & 29 & 28,2 \\
\hline Tidak diinginkan $(<40)$ & 9 & 8,7 \\
\hline \multicolumn{3}{|l|}{ Kadar LDL } \\
\hline Optimal $(<100)$ & 10 & 9,7 \\
\hline Mendekati optimal (100 - 129) & 15 & 14,6 \\
\hline Batas tinggi $(130-159)$ & 26 & 25,2 \\
\hline Tinggi $(160-189)$ & 37 & 35,9 \\
\hline Sangat tinggi $(>190)$ & 15 & 14,6 \\
\hline \multicolumn{3}{|l|}{ Kadar Ureum Plasma } \\
\hline $6-20$ & 84 & 81,6 \\
\hline$>20$ & 19 & 18,4 \\
\hline \multicolumn{3}{|l|}{ Kadar Kreatinin Plasma } \\
\hline $0,5-1,1$ & 89 & 86,4 \\
\hline$>1,1$ & 14 & 13,6 \\
\hline Total & 103 & 100 \\
\hline
\end{tabular}

\section{Hubungan Profil Lemak dengan Kadar Ureum dan Kreatinin}

Tabel 2 menunjukkan bahwa kadar trigliserida tidak memiliki hubungan yang bermakna terhadap perubahan kadar ureum pada ibu hamil dengan PEB. Namun kadar HDL memiliki hubungan yang bermakna terhadap perubahan kadar ureum pada ibu hamil dengan PEB. Selain itu, kadar LDL juga memiliki 
hubungan yang bermakna terhadap perubahan kadar ureum pada ibu hamil dengan PEB.

Tabel 2. Hubungan profil lemak dengan kadar ureum

\begin{tabular}{lccccc}
\hline \multirow{2}{*}{ Karakteristik } & \multicolumn{2}{c}{ Normal } & \multicolumn{2}{c}{ Meningkat } & \multirow{2}{*}{$\boldsymbol{p}$-value } \\
\cline { 2 - 5 } & $\mathbf{F}$ & $\mathbf{\%}$ & $\mathbf{F}$ & $\mathbf{\%}$ & \\
\hline Kadar Trigilserida & & & & & \\
$\quad$ Normal-Borderline & 8 & 7,8 & 1 & 1 & 0.477 \\
$\quad$ Tinggi & 76 & 73,8 & 18 & 17,5 & \\
Kadar HDL & & & & & \multirow{2}{*}{0,028} \\
$\quad$ Baik & 48 & 46,6 & 17 & 16,5 & \\
Tidak optimal & 27 & 26,2 & 2 & 1,9 & \\
Tidak diinginkan & 9 & 7,3 & 0 & 0 & \\
Kadar LDL & & & & & \\
Optimal & 59 & 8,7 & 1 & 1 & 0.017 \\
Mendekati optimal & 14 & 13,6 & 1 & 1 & \\
Batas Tinggi & 25 & 24,3 & 1 & 1 & \\
Tinggi & 26 & 25,2 & 11 & 10,7 & \\
Sangat Tinggi & 10 & 9,7 & 5 & 4,9 & \\
\hline
\end{tabular}

Tabel 3 menunjukkan bahwa kadar trigliserida tidak memiliki hubungan yang bermakna terhadap perubahan kadar kreatinin pada ibu hamil dengan PEB. Namun kadar HDL memiliki hubungan yang bermakna terhadap perubahan kadar kreatinin pada ibu hamil dengan PEB. Selain itu, kadar LDL juga memiliki hubungan yang bermakna terhadap perubahan kadar kreatinin pada ibu hamil dengan PEB.

Tabel 3. Hubungan profil lemak dengan kadar kreatinin

\begin{tabular}{lccccc}
\hline \multirow{2}{*}{ Karakteristik } & \multicolumn{2}{c}{ Normal } & \multicolumn{2}{c}{ Meningkat } & \multirow{2}{*}{$\boldsymbol{p}$-value } \\
\cline { 2 - 5 } & $\mathbf{F}$ & $\mathbf{\%}$ & $\mathbf{F}$ & $\mathbf{\%}$ & \\
\cline { 2 - 5 } Kadar Trigilserida & & & & & \\
$\quad$ Normal-Borderline & 9 & 8,7 & 0 & 0 & 0,253 \\
$\quad$ Tinggi & 80 & 77,7 & 14 & 13,6 & \\
Kadar HDL & & & & & \\
Baik & 51 & 49,5 & 14 & 13,6 & 0,001 \\
Tidak Optimal & 29 & 25,1 & 0 & 0 & \\
Tidak Diinginkan & 9 & 7,3 & 0 & 0 & \\
Kadar LDL & & & & & \\
Optimal & 10 & 9,7 & 0 & 0 & 0,001 \\
Mendekati optimal & 15 & 14,6 & 0 & 0 & \\
Batas Tinggi & 26 & 25,2 & 0 & 0 & \\
Tinggi & 27 & 26,2 & 10 & 9,7 & \\
Sangat Tinggi & 11 & 10,7 & 4 & 3,9 & \\
& & & & & \\
\hline
\end{tabular}

\section{Analisis Korelasi Profil Lipid terhadap Ureum dan Kreatinin}

Hasil yang didapatkan dari analisis korelasi Spearman dengan nilai signifikansi (Sig. 2 tailed $<0,05$ atau $<0,01)$, maka dapat disimpulkan bahwa hanya HDL maupun LDL secara parsial memiliki korelasi yang signifikan terhadap perubahan kadar ureum dan kreatinin. Sedangkan kadar trigiserida tidak menunjukkan korelasi yang signifikan terhadap perubahan kadar ureum dan kreatinin. 
Tabel 4. Analisis Korelasi TG, HDL, dan LDL Terhadap Ureum dan Kreatinin

\begin{tabular}{lcc}
\hline \multicolumn{1}{c}{ Parameter } & Koefisien Korelasi $=\mathbf{r}$ & $\boldsymbol{p}$-value \\
\hline TG Terhadap Ureum dan Kreatinin & & \\
Ureum & $-0,058$ & 0,563 \\
Kreatinin & 0,042 & 0,670 \\
HDL Terhadap Ureum dan Kreatinin & & \\
$\quad$ Ureum & 0,233 & 0,018 \\
$\quad$ Kreatinin & 0,269 & 0,006 \\
LDL Terhadap Ureum dan Kreatinin & & \\
$\quad$ Ureum & 0,256 & 0,009 \\
$\quad$ Kreatinin & 0,355 & 0,000 \\
\hline
\end{tabular}

Analisis Regresi Hubungan HDL dan LDL terhadap Ureum dan Kreatinin

Pada analisis regresi logistik didapatkan hasil bahwa variabel HDL memiliki OR 1,107, maka kadar HDL yang rendah lebih berisiko meningkatkan kadar kreatinin sebanyak 1,107 kali lipat pada ibu hamil dengan PEB. Pada variabel independen LDL hasil yang didapat menunjukkan bahwa LDL memberikan pengaruh parsial tidak signifikan $(\mathrm{p}>0,05)$.

Tabel 5. Analisis Regresi Logistik HDL dan LDL Terhadap Ureum dan Kreatinin

\begin{tabular}{lccccccc}
\hline \multicolumn{1}{c}{ Dependen variabel } & Parameter & B & S.E & Wald & df & Sig. & $\operatorname{Exp(B)}$ \\
\hline Ureum & HDL & 0.041 & 0.025 & 2.772 & 1 & 0.096 & 1.042 \\
\multirow{3}{*}{ Kreatinin } & LDL & 0.012 & 0.009 & 1.893 & 1 & 0.169 & 1.013 \\
& HDL & 0.102 & 0.041 & 6.235 & 1 & 0.013 & 1.107 \\
& LDL & 0.013 & 0.012 & 1.169 & 1 & 0.280 & 1.013 \\
\hline
\end{tabular}

\section{PEMBAHASAN}

Hasil studi menunjukkan bahwa usia ibu hamil yang mengalami PEB paling banyak ada di rentang usia 26 - 35 tahun yang merupakan rentang usia reproduksi produktif. Lee dkk $(2018)^{4}$ pada studinya juga menemukan bahwa pasien PE terjadi pada rentang umur 30,9 $\pm 4,1$ tahun. Sementara Udenze dkk (2016) ${ }^{10}$ mendapatkan data bahwa PEB terjadi pada ibu hamil dengan rentang umur $31,9 \pm 6,3$ tahun. Hal ini menjelaskan bahwa ibu hamil, baik pada rentang usia reproduksi produktif ( $<35$ tahun) maupun pada usia reproduksi dengan risiko (>35 tahun) memiliki risiko terjadi PE dan PEB. Untuk itu diperlukan antisipasi pencegahan berupa pemantauan selama kehamilan misalnya dengan ANC yang teratur. Pada penelitian ini didapatkan data bahwa PEB lebih banyak terjadi pada ibu hamil pada kehamilan kedua atau lebih. Hal yang sama juga dilaporkan oleh Ahmed dkk (2018) ${ }^{6}$ bahwa kejadian PE terjadi paling banyak pada kehamilan kedua, sementara Udenze dkk (2016) ${ }^{10}$ menemukan bahwa PE terjadi pada ibu hamil multiparitas. Hal ini dapat menjadi informasi untuk lebih berhati hati pada ibu hamil di kehamilan kedua. Walaupun tidak menutup kemungkinan PE atau PEB dapat terjadi pada ibu hamil dengan kehamilan pertama atau setelah beberapa kali hamil dan melahirkan yang mungkin disebabkan banyaknya faktor penyebab timbulnya PE atau PEB.

Perubahan fisiologis ibu dalam kehamilan sangat dipengaruhi oleh hormon plasenta, khususnya pada kehamilan trimester ketiga. Perubahan variasi kadar hormonal tersebut secara umum akan mempengaruhi metabolisme lipid dan glukosa pada ibu. Hal ini ditujukan 
agar janin menerima asuan nutrisi yang memadai untuk perkembangannya. Lebih lanjut, deposisi protein, lemak dan air dalam kompartemen selular pada tubuh akan mengarahkan pada terjadinya pertambahan berat badan ibu secara fisologis. Akibat peningkatan kebutuhan metabolik selama kehamilan, tubuh ibu akan merespon dengan mengalihkan penggunaan karbohidrat ke penggunaan lemak. Hal ini juga difasilitasi dengan terjadinya peningkatan dalam resistensi insulin dan konsentrasi hormonal lipolitik plasma. Perubahan ini juga mengarahkan pada variasi yang luas terhadap kadar insulin dan glukosa pada ibu hamil. Pada keadaan tidak makan, glukosa dipersiapkan untuk janin sementara sumber energi lain disediakan untuk memenuhi kebutuhan metabolik ibu. Pada keadaan hamil, konsentrasi trigliserida dan kolesterol total mengalami peningkatan. Peningkatan trigliserida dalam kehamilan disebutkan terjadi akibat 2 faktor, yaitu terjadinya peningkatan aktivitas lipase hepar yang akan menyebabkan peningkatan sintesis TG hepar dan menurunkan aktivitas lipoprotein lipase yang akan menyebabkan penurunan katabolisme jaringan adiposa. Jaringan adiposa putih merupakan organ endokrin aktif yang akan melepaskan faktor parakrin dan endokrin yang disebut adipokin. Perubahan dalam metabolisme lipid akan membantu ibu dan janin untuk beradaptasi. Konsentrasi trigliserida yang tinggi ditujukan untuk memenuhi kebutuhan metabolik ibu seraya tetap memenuhi kebutuhan glukosa untuk janin. ${ }^{11}$

Penelitian ini menunjukkan hasil bahwa Sebagian besar ibu hamil dengan PEB mengalami peningkatan kadar trigliserida, memiliki kadar HDL optimal serta kadar LDL yang tinggi. Hal ini juga ditemukan pada beberapa penelitian mengenai profil lipid pada preeklampsia. Udenze dkk (2016) pada penelitiannya menjelaskan bahwa pada pasien ibu hamil dengan preeklamsia berat mengalami peningkatan kadar triasilgliserol, LDL, dan kolesterol total serta penurunan kadar HDL. ${ }^{10}$ Ahmed dkk (2018) juga menemukan keadaan hipertrigliseridemia pada ibu hamil dengan preeklampsia yang disertai dengan peningkatan kadar kolesterol total, LDL, dan VLDL serta penurunan HDL. Pada penelitiannya, Ahmed dkk menjelaskan bahwa semakin berat preeklampsia yang dialami akan berkaitan dengan semakin tinggi kadar trigliserida, kolesterol, LDL, dan VLDL serta menurunnya kadar HDL. ${ }^{6}$ Hobiel dkk (2018) juga menunjukkan bahwa pada keadaan penurunan kadar HDL dan peningkatan kadar LDL akan meningkatkan risiko preeklamsia. ${ }^{12}$ Dislipidemia pada pasienPEB merupakan akibat dari stres oksidatif yang menyebabkan disfungsi endotel. Akumulasi lipid pada sel endotel vaskular akan mengganggu invasi trofoblas normal yang selanjutnya akan mengganggu produksi prostaglandin. ${ }^{4}$

Studi ini menunjukkan bahwa pada pasien PEB terdapat kadar TG yang tinggi, LDL tinggi serta HDL yang rendah di trimester ketiga. Keadaan tersebut menunjukkan terjadinya gangguan metabolisme lipid tubuh. Peningkatan kadar TG dan LDL selama kehamilan akan mengakibatkan akumulasi kolesterol yang dikaitkan dengan terjadinya inflamasi dan stres oksidatif serta proses atherosklerosis akut pada arteri spiralis plasenta. Hal ini akan menyebabkan terjadinya hipoksia plasenta yang mendasari terjadinya preeklampsia (PE). Studi terbaru menunjukkan bahwa ibu hamil dengan PE mengalami peningkatan adipocyte fatty acid binding proteins (AFABP), yang merupakan chaperone lipid intraselular yang akan mengkoordinasikan respon lipid dalam sel dan juga berkaitan erat dengan jalur inflammatorik dan jalur metabolik. Hal tersebut membuktikan bahwa lipoprotein kayatrigliserida berperan dalam patogenesis $\mathrm{PE}^{7}$ Alahakoon dkk (2020) ${ }^{13}$ dalam studinya juga mendapatkan bahwa pada ibu hamil dengan PE didapat peningkatan kadar TG yang lebih tinggi dibandingkan dengan kadar HDL atau LDL. Hal ini dikaitkan dengan peran dislipidemia pada pathogenesis PE dan kelainan vaskular lainnya. ${ }^{13}$ Perubahan kadar HDL dan LDL pada ibu hamil dengan PE juga dilaporkan oleh Leon-Reyes dkk (2017). Pada studinya LeonReyes dkk menjelaskan bahwa perubahan kadar HDL dan LDL berkaitan erat dengan keadaan stress oksidatif yang terjadi pada PE. Penelitian ini menunjukkan hasil yang sama dengan hasil Leon-Reyes dkk bahwa ditemukan lebih banyak peningkatan kadar LDL plasma pada ibu hamil dengan PE, dan kadar HDL plasma ditemukan tidak meningkat. Dijelaskan bahwa partikel LDL dan HDL bersifat rentan terhadap stress oksidatif yang terjadi. Perubahan lipid plasma dan apolipoprotein merupakan sumber terjadinya lipoperoksidasi dan stress oksidatif 
yang akan merupakan salah satu jalur penyebab disfungsi endothelial. ${ }^{14}$

Studi ini juga menunjukkan terjadinya perubahan kadar ureum dan kreatinin pada ibu hamil dengan PEB walau hanya dalam jumlah kecil. Selain itu, pada analisa korelasi juga ditemukan bahwa kadar HDL yang tidak optimal dan kadar LDL yang tidak diinginkan memiliki hubungan dengan terjadinya peningkatan kadar ureum dan kreatinin pada PEB. Pada analisis regresi logistik ditemukan bahwa penurunan kadar HDL akan meningkatkan risiko terjadinya peningkatan kadar kreatinin. Semua hasil analisis tersebut menunjukkan bahwa perubahan lipid darah, dalam hal ini kadar HDL dan LDL, memiliki peran untuk terjadinya perubahan fungsi ginjal, dalam hal ini yaitu dalam perubahan kadar ureum dan kreatinin ibu hamil dengan preeklampsia berat. Babu et al (2015) menjelaskan dalam penelitiannya bahwa pada pasien dengan preeklampsia menunjukkan tanda yang jelas dari kerusakan ginjal yaitu dengan terjadinya peningkatan serum ureum, kreatinin, dan rendahnya kadar estimated glomerular filtration rate (eGFR) $)^{15}$ Ekun et al (2018) juga menjelaskan dalam penelitiannya bahwa terjadi peningkatan kadar ureum, kreatinin, asam urat dan mikroalbuminuria pada kelompok dengan ibu hamil dengan preeklampsia. Preeklampsia dikaitkan dengan terjadinya efek yang merugikan pada fungsi ginjal. ${ }^{16}$

Pada kehamilan, peningkatan curah jantung serta peningkatan volume intraselular dan ekstraselular merupakan hal yang fisiologis. Keadaan ini juga disertai dengan pembesaran ginjal akibat adanya retensi cairan dan kesulitan urin untuk mengalir secara baik dari ginjal ke kandung kemih yang terjadi lebih karena adanya peningkatan pada sistem vaskular dan volume cairan interstitial ginjal. Perubahan struktural ginjal selama kehamilan juga dipengaruhi oleh faktor hormonal dan mekanikal. Perubahan hormonal akan menyebabkan perubahan fungsi ginjal dengan terjadinya peningkatan renal plasma flow (RPF) dan glomerular filtration rate (GFR) sebagai akibat dari curah jantung yang meningkat. Pada kehamilan normal, tekanan intraglomerulus akan tidak berubah walaupun terjadi perubahan RPF. Hal ini terjadi akibat efek kompensatorik dari arteriol afferent dan efferent ${ }^{17}$ Terjadinya perubahan kadar kreatinin dan ureum darah pada preeklampsia pada beberapa studi menjelaskan bahwa wanita dengan preeklampsia mengalami penurunan GFR dan penurunan RPF. Peningkatan kadar kreatinin dapat disebabkan oleh penurunan klirens urin yang terjadi sekunder akibat penurunan GFR dan peningkatan reabsorpsi ${ }^{16}$

Adank dkk (2019) menjelaskan bahwa hiperlipidemia maternal pada ibu hamil dengan preeklampsia merupakan faktor risiko untuk inisiasi dan perkembangan atherosklerosis. Adank dkk menjelaskan hipotesisnya bahwa profil lipid atherogenik pada waita hamil dengan preeklampsia meningkatkan risiko kerusakan endotelial melalui mekanisme stres oksidatif pada dinding sel arterial. $^{7}$ Jammalamadaga dkk (2017) menjelaskan pada penelitiannya bahwa hiperlipidemia pada wanita preeklamsia akan mengakibatkan ketidakseimbangan faktor angiogenik dan antiangiogenik yang selanjutnya akan mengakibatkan keadaan stres oksidatif dan kerusakan endotelial sehingga terjadi kebocoran faktor janin dan placenta-derived factors ke sirkulasi maternal yang selanjutnya akan menyebabkan kerusakan endotel maternal, stres oksidasi semakin meningkat dan terjadi inflamasi sistemik. ${ }^{18}$

Craici dkk (2014) menjelaskan bahwa endothelin-1, vasokonstriktor kuat yang bekerja pada reseptor endotelin tipe $\mathrm{A}$, berperan sebagai penghubung dalam kerusakan podosit ginjal dan keadaan preeklampsia yang berkaitan dengan stres oksidasi dan disfungsi endotel. ${ }^{19}$ Keadaan dislipidemia pada wanita dengan preeklampsia akan menyebabkan stres oksidasi yang akan mengakibatkan disfungsi endotel yang selanjutnya akan menyebabkan kerusakan jaringan dan inflamasi sistemik, dalam hal ini juga akan meningkatkan risiko kerusakan podosit ginjal dan perubahan struktur ginjal yang akan mengakibatkan perubahan fungsi ginjal.

Dari studi, didapatkan keadaan dislipidemia ini dipengaruhi oleh kadar TG, HDL, dan LDL, namun secara statistik didapatkan bahwa HDL lebih berperan dalam kejadian PEB sehingga ibu hamil dengan HDL yang lebih tinggi (OR 1,107) akan dapat menurunkan kadar kreatinin yang selanjutnya dapat mengurangi kejadian penurunan fungsi ginjal secara signifikan. 


\section{KESIMPULAN}

Penelitian ini ditujukan untuk mengetahui hubungan antara profil lipid darah terhadap gangguan fungsi ginjal pada ibu hamil dengan preeklampsia berat di RSUD Kelas B Serang periode Januari - Desember 2018. Pada penelitian ini ditemukan peningkatan kadar TG dan LDL serta penurunan kadar HDL pada ibu hamil dengan PEB. Analisis data menunjukkan hubungan yang bermakna antara perubahan profil lipid pasien PEB, dalam hal ini kadar HDL dan LDL, terhadap perubahan kadar ureum dan kreatinin yang menggambarkan fungsi ginjal ibu hamil dengan PEB. Penurunan kadar HDL memiliki kemungkinan risiko peningkatan kadar kreatinin sebanyak 1,107 kali lipat pada ibu hamil dengan PEB. Keadaan dislipidemia pada keadaan PEB akan menyebabkan stres oksidasi dan keadaan disfungsi endotel yang selanjutnya dapat menyebabkan perubahan struktur glomerulus dan perubahan fungsi ginjal. Dengan hasil studi ini diharapkan ibu hamil dapat menjaga asupan pola makan dan kandungan makanan sehingga tidak mengandung lemak/lipid yang berlebihan yang dapat memicu terjadinya PE/PEB.

\section{SARAN}

Keadaan PEB dapat mengancam nyawa dan meningkatkan risiko kematian maternal. Disarankan kepada fasilitas pelayanan kesehatan (fasyankes) untuk lebih memperhatikan kondisi ibu hamil pada saat melakukan Ante Natal Care (ANC) agar PE dan PEB terdeteksi lebih awal dan dapat ditatalaksana dengan tepat. Selain itu, membantu memotivasi ibu untuk melakukan ANC secara lebih teratur.

\section{UCAPAN TERIMA KASIH}

Terima kasih tak terhingga kami ucapkan kepada LPPM UPNVJ yang telah bersedia mendanai penelitian ini dan seluruh pihak di RSUD Dr. Drajat Prawiranegara Serang yang telah memberikan kemudahan kepada tim peneliti sehingga dapat menyelesaikan penelitian ini.

\section{DAFTAR PUSTAKA}

1. World Health Organization. Maternal mortality: level and trends 2000 to 2017. Sexual and Reproductive Health.2019.12 p.

2. Hale AL, Nilay K, Kemal AY, Erol A, Hospital GM, Science H, et al. The role of hematological and biochemical markers in preeclampsia prediction. J Clin Anal Med. 2017;8(Suplement 4).

3. Gathiram P, Moodley J. Pre-eclampsia: Its pathogenesis and pathophysiolgy. Cardiovasc J Afr. 2016;27(2):71-8.

4. Lee SM, Moon JY, Lim BY, Kim SM, Park $\mathrm{CW}$, Kim BJ, et al. Increased biosynthesis and accumulation of cholesterol in maternal plasma, but not amniotic fluid in preeclampsia. Sci Rep. 2019;9(1):1-8.

5. Van Der Graaf AM, Toering TJ, Faas MM, Titia Lely A. From preeclampsia to renal disease: A role of angiogenic factors and the renin-angiotensin aldosterone system? Nephrol Dial Transplant. 2012;27(SUPPL. 3):51-7.

6. Ahmed AAM, El Omda, Samir FAA, Mousa MSM. Maternal Lipid Profile as A Risk Factor for Preeclampsia. Egypt J Hosp Med. 2018;71(April):3434-8.

7. Adank MC, Benschop L, Peterbroers KR, Smak Gregoor AM, Kors AW, Mulder MT, et al. Is maternal lipid profile in early pregnancy associated with pregnancy complications and blood pressure in pregnancy and long term postpartum? Am J Obstet Gynecol. 2019;221(2):150.e1150.e13.

8. Arsana PM, Rosandi R, Manaf A, Budhiarta A, Hikmat Permana. Panduan Pengelolaan Dislipidemi di Indonesia 2019. Pb Perkeni. 2019;9.

9. Pendidikan P, Spesialis D, Klinik P, Sakit R, Sadikin H. Pemeriksaan Fungsi Ginjal. 2016;43(2):148-54.

10. Udenze I, Okusanya B, Soriyan O, Ajie I, Egbuagha E. Circulating levels of plasma lipids and cardiovascular risk in Nigerian women with severe preeclampsia. J Clin Sci. 2016;13(2):72.

11. Pusukuru R, Shenoi AS, Kyada PK, Ghodke B, Mehta V, Bhuta K, et al. 
Evaluation of lipid profile in second and third trimester of pregnancy. J Clin Diagnostic Res. 2016;10(3):QC12-6.

12. Hobiel HA, Tadros HYZ. Oxidative Stress and Dyslipidemia as Indicators of Pathogenesis of Preeclampsia in Pregnant Sudanese Women. J Biosci Med. 2018;06(07):48-65.

13. Alahakoon TI, Medbury HJ, Williams H, Lee VW. Lipid profiling in maternal and fetal circulations in preeclampsia and fetal growth restriction-a prospective case control observational study. BMC Pregnancy Childbirth. 2020;20(1):61.

14. León-Reyes G, Maida-Claros RF, UrrutiaMedina AX, Jorge-Galarza E, GuzmánGrenfell AM, Fuentes-García $S$, et al. Oxidative profiles of LDL and HDL isolated from women with preeclampsia. Lipids Health Dis. 2017;16(1):1-9.

15. Babu RP, Christy A, Hegde A, Manjrekar P, Joseph M. Microalbuminuria - A better marker in hypertensive disorders of pregnancy. Saudi J Kidney Dis Transpl. 2015;26(5):941-6.

16. Ekun OA, Olawumi OM, Makwe CC, Ogidi NO. Biochemical Assessment of Renal and Liver Function among Preeclamptics in Lagos Metropolis. Int J Reprod Med. 2018;2018:1-6.

17. Bawah AT, Kuffour FAO, Boateng MA, Mustapha M, Amoah P, Ussher FA, et al. Pregnant Women at the Volta Regional Hospital. 2018;(4):166-71.

18. Jammalamadaga $\mathrm{V} \quad \mathrm{S}$, Abraham $\mathrm{P}$. Abnormal lipid metabolism is associated with angiogenic and anti angiogenic factor imbalance in PIH women. Int J Reprod Contraception, Obstet Gynecol. 2017;6(9):3983-8.

19. Craici IM, Wagner SJ, Weissgerber TL, Joseph P, Garovic VD, Clinic M, et al. HHS Public Access. 2015;86(2):275-85. 